УДК 341.492 .2

\title{
МЕЖДУНАРОДНОЕ ПРАВО В ОПЕРАТИВНО-СЛУЖЕБНОЙ ДЕЯТЕЛЬНОСТИ ПРАВООХРАНИТЕЛЬНЫХ ОРГАНОВ РЕСПУБЛИКИ БЕЛАРУСЬ
}

\author{
А.И. БОРОДИЧ \\ канд. юрид. наук, доцент, доцент кафедры конституционного и международного права \\ Академия Министерства внутренних дел Республики Беларусь, г. Минск
}

\section{Аннотация}

В целях противодействия современным вызовам и угрозам в сфере правопорядка, которые представляет транснациональная организованная преступность, необходима консолидаџия усилий всего международного сообщества, предполагающая регулирование деятельности государств (их правоохранительных органов) путем воздействия международного права на межгосударственные отношения.

Рассматривается роль международного права в оперативно-служебной деятельности правоохранительных органов по противодействию транснациональной организованной преступности.

Abstract

In order to counteract modern challenges and threats in the sphere of law and order which are presented by transnational organized crime, it is necessary to consolidate the efforts of the international community, suggesting regulation of the States activity (their law enforcement agencies) by the impact of the international law on the interstate relations.

The role of international law in the operational and official activity of law enforcement agencies in combating transnational organized crime is considered.

\section{ВВЕДЕНИЕ}

Территория Республики Беларусь, в силу своего географического положения, вовлечена во многие сферы трансграничной преступной деятельности. Террористическая деятельность, противоправные посягательства на жизнь и здоровье человека, деятельность, связанная с торговлей людьми, в том числе сексуальной эксплуатацией или вовлечением в занятие проституцией, незаконная миграция, хищение или незаконный оборот ядерных материалов и радиоактивных веществ, незаконный оборот наркотических средств, психотропных веществ и их прекурсоров, оружия и боеприпасов к нему, взрывных устройств и взрывчатых веществ, контрабанда и др. создают наибольшую угрозу национальной безопасности. Каждая из перечисленных сфер, представляет собой форму криминального бизнеса, активно консолидируется в международном масштабе, имеет высокий уровень профессионализма и организованности. Поэтому цель Конвенции ООН против транснациональной организованной преступности (г. Нью-Йорк, 15.11.2000) [1] заключается в содействии сотрудничеству государств в деле более эффективного предупреждения транснациональной организованной преступности и борьбы с ней.

В связи с этим, юридическими функциями международного права можно считать: стабилизирующую (международные правовые нормы призваны организовывать мировое сообщество, устанавливать определенный международный правопорядок, стремиться упрочить его сделать более стабильным); регулятивную (международные правовые нормы наделяют участников международных отношений определенными правами и обязанностями); охранительную (обеспечение надлежащей охраны международных правоотношений).

Международное право выполняет в международных отношениях координирующую (в его нормах отражаются общеприемлемые для государств стандарты поведения в различных областях взаимоотношений, расширяя и углубляя взаимосвязи между государствами) и информационно-воспитательную функцию (состоит в передаче накопленного опыта упорядоченного поведения государств, в воспитании в духе уважения к праву, к охраняемым им интересам и ценностям).

\section{РЕЗУЛЬТАТЫ И ИХ ОБСУЖДЕНИЕ}

К деятельности правоохранительных органов Республики Беларусь и их структурных подразделений в сферах, где ощутимо взаимодействие с международным правовым регулированием, имеют отношения законы - о гражданстве Республики Беларусь, о правовом положении иностранных граждан и лиц без гражданства в Республике Беларусь, о противодействии торговле людьми, о порядке выезда из Республики Беларусь и въезда в Республику Беларусь граждан Республики Беларусь, о предоставлении иностранным гражданам и лицам без гражданства статуса беженца, дополнительной и временной защиты в Республике Беларусь о внешней трудовой миграции, об оперативно-розыскной деятельности, а также Кодекс Республики Беларусь об административных правонарушениях, Уголовный кодекс Республики Беларусь и др.

Непосредственная регламентация функций и действий учреждений МВД, содержащаяся в Законе Республики Беларусь «Об органах внутренних дел Республики Беларусь» от 17.07.2007 [2] определяет, что взаимодействие орга- 
нов внутренних дел с иностранными организациями осуществляется в соответствии с законодательными актами и международными договорами Республики Беларусь (ст. 7).

В Положении о Государственном таможенном комитете Республики Беларусь (в ред. Указа Президента Республики Беларусь от 13.11.2014 № 530) в п. 8.7 главы 2 (Основные задачи ГТК) сказано: «обеспечение выполнения международных обязательств Республики Беларусь в части, касающейся таможенного дела» [3].

Органы пограничной службы взаимодействие с компетентными органами иностранных государств и международными организациями осуществляют в соответствии с законодательными актами Республики Беларусь и международными договорами (ст. 6 Закона Республики Беларусь «Об органах пограничной службы Республики Беларусь» от 11.11.2008) [4].

Согласно Закону Республики Беларусь «Об органах финансовых расследований Комитета Государственного контроля Республики Беларусь» от 16.07.2008 взаимодействие органов финансовых расследований с правоохранительными и контролирующими органами иностранных государств осуществляется в соответствии с законодательными актами и международными договорами Республики Беларусь (ст. 6) [5].

Вместе с тем следует отметить, что Положение о Министерстве внутренних дел Республики Беларусь (в ред. Указов Президента Республики Беларусь от 12.05.2009 № 241, от 24.09.2009 № 475, от 27.09.2010 № 499, от 02.10.2010 № 519, от 06.10.2011 № 450, от 06.01.2012 № 17, от 05.04.2012 № 157, от 08.01.2013 № 8) [6], включает пункт 9.18., согласно которому Министерство осуществляет международное сотрудничество, участвует в разработке проектов международных договоров Республики Беларусь, заключении международных договоров Республики Беларусь, в том числе межведомственного характера, оказывает иностранным государствам услуги по подготовке кадров.

Согласно Указу Президента Республики Беларусь «Об образовании Следственного комитета Республики Беларусь» от 12.09.2011 [7] одной из основных задач является осуществление в пределах своей компетенции международного сотрудничества в сфере досудебного уголовного производства.

В соответствии с конституционными нормами в законах, затрагивающих деятельность правоохранительных органов Республики Беларусь, содержатся формулировки, обусловленные международными правовыми нормами. Имеются в виду главным образом международные пакты и конвенции о правах и свободах человека и гражданина. Например, в Законе Республики Беларусь «Об оперативно-розыскной деятельности» от 9.07.1999 правовую основу оперативно-розыскной деятельности составляют Конституция Республики Беларусь, настоящий Закон, иные акты законодательства, в том числе международные договоры Республики Беларусь (ст. 5) [8].

Обусловленность правоприменительных актов в системе правоохранительных органов международными договорами Республики Беларусь имеет различные проявления. Так, Закон Республики Беларусь «О борьбе с организованной преступностью» от 27.06.2007 (в ред. Законов Республики Беларусь от 28.12.2009 № 78-3, от 14.06.2010 № 132-3, от 12.12.2013 № 84-3) [9] определил, что правовую основу деятельности по борьбе с организованной преступностью составляют Конституция Республики Беларусь, настоящий Закон, указы и декреты Президента Республики Беларусь, Конвенция ООН против транснациональной организованной преступности от 15.11.2000 и дополняющие ее протоколы, ратифицированные Республикой Беларусь, другие международные договоры, действующие для Республики Беларусь, и иные акты законодательства Республики Беларусь. Если международным договором установлены иные правила, чем те, которые содержатся в настоящем Законе, то применяются правила международного договора.

Реализация Закона Республики Беларусь «О правовом положении иностранных граждан и лиц без гражданства в Республике Беларусь» сопряжена с надлежащим пониманием и применением международных договоров относительно визового и безвизового въезда в Республику Беларусь и пребывания на ее территории. В частности, иностранцы, прибывшие в Республику Беларусь, кроме иностранцев, указанных в статье 45 настоящего Закона, обязаны в течение пяти суток, за исключением выходных дней, государственных праздников и праздничных дней, установленных и объявленных Президентом Республики Беларусь нерабочими, зарегистрироваться в органе регистрации по месту фактического временного пребывания, если иное не определено настоящим Законом и международными договорами Республики Беларусь (ч. 1 ст. 41). В данном случае под иным порядком подразумеваются правила двусторонних соглашений с некоторыми странами об отмене виз, т.е. о безвизовом въезде и пребывании на территории соответствующих стран. В рамках Содружества Независимых Государств действует Соглашение о безвизовом передвижении граждан государств Содружества по территории его участников. Очевидно, значение установленных договорных правил в этой сфере для действий органов внутренних дел.

Особое место в компетенции МВД занимают вопросы взаимоотношений с Международной организацией уголовной полиции (Интерполом). Имеется в виду, прежде всего, правовой статус Национального центрального бюро (НЦБ) Интерпола, который определен национальным законодательством Республики Беларусь, Уставом международной организации уголовной полиции - Интерпол, Постановлением МВД и Генеральной прокуратуры Республики Беларусь от 30.10.2012 № 386дсп/35 «Об утверждении Инструкции об обеспечении информационного взаимодействия в рамках Интерпола», Положением о НЦБ Интерпола в Республике Беларусь: Приказ МВД Республики Беларусь от 28.02.2012 г. № 66 [10].

НЦБ в качестве подразделения криминальной полиции входит в состав центрального аппарата МВД. На него возложено сотрудничество правоохранительных и других государственных органов Республики Беларусь с правоохранительными органами иностранных государств-членов Интерпола и Генеральным секретариатом Интерпола. НЦБ Интерпола в своей деятельности, наряду с национальными нормативными правовыми актами, руководствуется международными договорами Республики Беларусь, общепризнанными принципами и нормами международного права, Уставом Интерпола, обязательными решениями Генеральной Ассамблеи Интерпола. 
Правоохранительные органы Республики Беларусь на основе международных норм осуществляют взаимодействие с соответствующими органами зарубежных стран. Например, Министерство внутренних дел как государственный орган исполнительной власти, компетентен заключать от имени Республики Беларусь международные договоры межведомственного характера. Вместе с тем оно обеспечивает в пределах своих полномочий выполнение обязательств Белорусской Стороны по договорам и осуществление прав Белорусской Стороны, вытекающих из этих договоров.

В практике международных отношений действуют двусторонние соглашения о сотрудничестве с министерствами внутренних дел Латвийской Республики, Республики Польша, Итальянской Республики, Литовской Республики, Республики Болгария, Румынии, Турции, Республики Судан, Объединенных Арабских Эмиратов и других стран, с Министерством общественной безопасности Социалистической Республики Вьетнам, Китайской Народной Республики.

Следственным комитетом Республики Беларусь заключено соглашение о сотрудничестве со Следственным комитетом Российской Федерации (вступило в силу 25.04.2013). Сотрудничество в рамках своей компетенции осуществляется по следующим основным направлениям: организация и обеспечение исполнения международных договоров в уголовно-правовой сфере, участниками которых являются государства Сторон; борьба с преступностью, в том числе в ее организованных формах, терроризмом, коррупцией, незаконным оборотом оружия, наркотических средств и психотропных веществ, преступлениями в сфере экономики и высоких технологий и иными видами преступлений, представляющих повышенную угрозу для общества; обеспечение защиты прав и свобод человека и гражданина; подготовка и повышение квалификации кадров для органов предварительного следствия; научно-исследовательская деятельность по вопросам, представляющим взаимный интерес.

Богатый опыт сотрудничества накоплен в рамках СНГ. Помимо двусторонних соглашений почти со всеми членами Содружества сложился комплекс многосторонних соглашений, в числе которых наряду с основным Соглашением о взаимодействии министров внутренних дел независимых государств в сфере борьбы с преступностью от 24.04.1992 имеют такие специфические документы, как Соглашения о порядке передачи и транзитной перевозки лиц, взятых под стражу, Соглашение о борьбе с преступностью на транспорте.

В целях взаимодействия и координации в борьбе с преступностью созданы:

в 1996 г. Совет Министров внутренних дел государств-участников СНГ. Функции рабочего аппарата выполняет Бюро по координации борьбы с организованной преступностью и иными опасными видами преступлений на территории государств-участников СНГ (БКБОП). Основные задачи БКБОП: формирование специализированного банка данных и предоставление информации в соответствующие МВД; содействие в осуществлении международного розыска участников преступных сообществ и лиц, совершивших наиболее опасные преступления и скрывающихся от уголовного преследования; обеспечение согласованных действий при проведении оперативнорозыскных мероприятий и комплексных операций, затрагивающих интересы нескольких стран СНГ, выработка рекомендаций по борьбе с транснациональной преступностью;

Совет руководителей органов безопасности и специальных служб СНГ (СОРБ) создан 28.03.1997 в целях взаимодействия и координации действий в борьбе с организованной преступностью международного характера и в других согласованных сферах деятельности органов безопасности и спецслужб государств-участников СНГ;

Координационый совет руководителей органов налоговых (финансовых) расследований государствучастников СНГ (КСОНР) создан решением руководителей органов налоговых (финансовых) расследований государств-участников СНГ 20.10.1999 для взаимодействия и координации действий в борьбе с нарушениями налогового (финансового) законодательства;

Совместная комиссия государств-участников Соглашения о сотрудничестве государств-участников СНГ в борьбе с незаконной миграцией создана 6.03.1998; 1.12.2000;

Антитеррористический центр государств-участников СНГ создан Решением Совета глав государств СНГ от

Совет командующих Пограничными войсками СНГ является головным органом Совета глав государств СНГ по вопросам координации взаимодействия пограничных ведомств государств-участников СНГ в сфере обеспечения согласованной пограничной политики на внешних границах государств-участников СНГ;

Совет руководителей миграционных органов государств-участников СНГ образован 5.10.2007. Совет является органом отраслевого сотрудничества СНГ и предназначен для обеспечения координации взаимодействия и решения вопросов в области миграционной политики;

Совет руководителей таможенных служб государств-участников СНГ является постоянно действующим органом отраслевого сотрудничества СНГ и предназначен для обеспечения координации взаимодействия таможенных служб государств-участников СНГ в области таможенной политики;

Координационный совет генеральных прокуроров государств-участников СНГ является межгосударственным органом Содружества, организующим сотрудничество и взаимодействие генеральных прокуратур, прокуратур государств-участников СНГ в сферах обеспечения законности, прав и свобод человека и гражданина, борьбы с преступностью;

Совет руководителей подразделений финансовой разведки государств-участников СНГ является органом отраслевого сотрудничества СНГ и предназначен для обеспечения организации и координации противодействия легализации (отмыванию) преступных доходов и финансированию терроризма; 
Межгосударственный Совет по противодействию коррупции создан Соглашением об его образовании, подписанным 25.10.2013.

\section{ВЫВОДЫ}

Таким образом, современные международные отношения характеризуются большой взаимозависимостью государств. Ни одно государство не может противостоять транснациональной организованной преступности изолированно и учитывать только свои национальные интересы. Поэтому, международное право в оперативно-служебной деятельности правоохранительных органов Республики Беларусь, играет существенную роль. В современных условиях роль международного права заключается в регулировании деятельности государств (их правоохранительных органов) на международной арене, в том числе в противодействии современным вызовам и угрозам в сфере правопорядка.

\section{ЛИТЕРАТУРА}

1. Конвенции ООН против транснациональной организованной преступности (г. Нью-Йорк, 15.11.2000) [Электронный ресурс] // Консультант Плюс: Беларусь. Технология-3000 / ООО «ЮрСпектр». - Минск, 2015.

2. Закон Республики Беларусь «Об органах внутренних дел Республики Беларусь» от 17.07.2007 [Электронный ресурс] // Консультант Плюс: Беларусь. Технология-3000 / ООО «ЮрСпектр». - Минск, 2015.

3. Положение о Государственном таможенном комитете Республики Беларусь (в ред. Указа Президента Республики Беларусь от 13.11.2014 № 530) [Электронный ресурс] // Консультант Плюс: Беларусь. Технология-3000 / ООО «ЮрСпектр». - Минск, 2015.

4. Закон Республики Беларусь «Об органах пограничной службы Республики Беларусь» от 11.11.2008 [Электронный ресурс] // Консультант Плюс: Беларусь. Технология-3000 / ООО «ЮрСпектр». - Минск, 2015.

5. Закон Республики Беларусь «Об органах финансовых расследований Комитета Государственного контроля Республики Беларусь» от 16.07.2008 [Электронный ресурс] // Консультант Плюс: Беларусь. Технология-3000 / ООО «ЮрСпектр». - Минск, 2015.

6. Положение о Министерстве внутренних дел Республики Беларусь (в ред. Указов Президента Республики Беларусь от 12.05.2009 № 241, от 24.09.2009 № 475, от 27.09.2010 № 499, от 02.10.2010 № 519, от 06.10.2011 № 450, от 06.01.2012 № 17, от 05.04.2012 № 157, от 08.01.2013 № 8 [Электронный ресурс] // Консультант Плюс: Беларусь. Технология-3000 / ООО «ЮрСпектр». - Минск, 2015.

7. Указ Президента Республики Беларусь «Об образовании Следственного комитета Республики Беларусь» от 12.09.2011 [Электронный ресурс] // Консультант Плюс: Беларусь. Технология-3000 / ООО «ЮрСпектр». - Минск, 2015.

8. Закон Республики Беларусь «Об оперативно-розыскной деятельности» от 9.07.1999 [Электронный ресурс] // Консультант Плюс: Беларусь. Технология-3000 / ООО «ЮрСпектр». - Минск, 2015.

9. Закон Республики Беларусь «О борьбе с организованной преступностью» от 27.06 .2007 (в ред. Законов Республики Беларусь от 28.12.2009 № 78-3, от 14.06.2010 № 132-3 [Электронный ресурс] // Консультант Плюс: Беларусь. Технология-3000 / ООО «ЮрСпектр». - Минск, 2015.

10. Постановление МВД и Генеральной прокуратуры Республики Беларусь от 30.10 .2012 № $386 д с п / 35$ «Об утверждении Инструкции об обеспечении информационного взаимодействия в рамках Интерпола», Положением о НЦБ Интерпола в Республике Беларусь: Приказ МВД Республики Беларусь от 28.02.2012 г. № 66 [Электронный ресурс] // Консультант Плюс: Беларусь. Технология-3000 / ООО «ЮрСпектр». - Минск, 2015.

Статья поступила в редакциию 10 июля 2015 года. 